\title{
Illocutionary Acts In Oprah's Lifeclass Talk Show
}

\author{
Ni Wayan Kasni ${ }^{1}$, Putu Lina Damayanthi ${ }^{2}$ \\ Universitas Warmadewa Denpasar-Bali, Indonesia ${ }^{1,2}$ \\ \{wayankasni@gmail.com $\left.{ }^{1}\right\}$
}

\begin{abstract}
The aim of the research are to find out the kinds of illocutionary acts in Oprah's Lifeclass Talk show and to explain how the types of illocutionary are expressed. The theoretical basis used in this research is taken from J.R Searle (1969). Researcher also apply the other theories that are considered relevant to this study. The data used in this study were taken from the conversation between Oprah Winfrey and her guests. All of the data are collected and classified based on the type of illocutionary acts. Observation and note taking are the method of data collection. The problem is described descriptively according the appropriate theory applied. Based on the result of analysis, the kind of illocutionary act consist into commisives to commit him or herself to showed of action. Second, the speakers made directives to command or request someone to do an action. Third, expressives kind to express the psychological condition about the situation or state, like pleasure or sadness. Fourth, representatives or assertives to represent a statement. Furthermore, the declaration type is not found in this research. It is expected that this research totally contributes important study for the next researcher who are interested in doing the same kind of study.
\end{abstract}

Keywords: Speech Act; Locutionary; Illocutionary; Perlocutionary; Talkshow

\section{Introduction}

An investigation of language that looks at logical significance of language including speaker's goal and listener's reaction or response is called as pragmatics. Pragmatics is the investigation of those setting subordinate parts of importance which are deliberately preoccupied away from in the development of substance intelligent structure. Pragmatics is worried about the investigation of importance as conveyed by a speaker and deciphered by a listener. Speech acts is the utterance which speaker says or speaker performs in every speech or performative capacity in language in correspondence. Practically any discourse demonstration is actually the presentation of a few demonstrations without a moment's delay, recognized by various parts of the speaker's aim: there is the demonstration of saying something, what one does in saying it, for example, requesting or promising, and how one is attempting to influence one's audience. Normally, a speaker talks to the hearer with the certain purposes while the hearer tries to understood the speaker's goal. They are usually assisted in understanding meanings of utterances by the circumstances around them.

In every speech act we can determine three things, following. What is said, the utterance, can be called the locution. What the speaker intends to communicate to the addressee is 
illocution. The message that the addressee gets, his interpretation of what the speaker says, is perlocution. If the communication is successful, the illocution and the perlocution are alike or nearly same.

In actuality discourse acts is often utilized in every day social communications around us. By talking, an individual plays out a demonstration or accomplishes something. At the point when the speaker creates an expression, it implies the speaker is playing out a specific sorts of act, for example, providing request, posing inquiry, making request or promises. These kinds of act is called speech act.

People made speech acts when they express an apology, complaint, greeting, ordering, promising, invitation, request, or refusal. The one significance of contemplating speech act is to cause us to fathom what message that found in each expression. Speech acts simply act in discussion or exchange which performed by speaker and listener. Speech acts can be studied in communicative event, for example in talk show. A Talk Show is a television programming genre in which one person (or group of people) discusses various topic put forth by a talk show host. A Talk shows are often meant to entertain, and many feature comedy or entertainers performing and typically discusses different points, similar to governmental issues, tattle, issues, celebrity outrages and etc, syndicated programs highlight a board of visitors, for the most part comprising of a gathering of people who are found out or who have extraordinary involvement with connection to whatever issue is being talked about on the show for that scene.

A number latest related research has been carried out. The first latest related research was about the illocution on discourse demonstrations of foreign understudies in Indonesian learning. Utterances that containing illocutionary force in learning activities were assertive, declaration, directives, commissive, and expressive. And the second latest related research was about Illocutionary acts of Chinese in Pematangsiantar. This second related research found that the sorts of illocutionary acts happened in the utterances of Chinese who live in Hos Cokroaminoto, Pematangsiantar are Representative (ordinary of structure asking expression), Directive (normal of structure expression of requesting and inviting), Expressive (common of structure articulations of greeting and compliment), and Commissive (common place of structure expression of compromising).. The third latest related research was about Illocutionary acts of

The scopes of discussion that will be analyzed are what kinds of Illocutionary Acts that found in Oprah's Lifeclass Talk Show? And how did they express the types of Illocutionary Acts in the Oprah's Lifeclass Talk Show? Therefore, the aim of this paper to find out the type of illocutionary acts in Oprah's Lifeclass Talk show and to explain how the types of illocutionary are expressed. The result of the research there are 30 utterances of directives illocutionary acts . Each of the utterances divided into a part of directive illocutionary act . The data were classified into five namely are, directives (10), assertives (5) declaratives (2), commissives (4), expressives (9).

\section{Methods}

The data of this research were taken from the video Oprah's Lifeclass Talk Show. This research prefer on finding the types of illocutionary act in the talk show Oprah Winfrey and their guest by using theory of Searle (1969). Data in this research were collected from YouTube and Oprah Winfrey Network on oprah.com, then downloaded talk show Oprah's Lifeclass, observed the video from Oprah's Lifeclass which has 63 list of episodes in 5 seasons, and in this research Oprah has 4 guest, they are Jim Carrey, J.K. Rowling, Sara Blakely, and Ralph 
Lauren. After that, from this video the writer used note taking method with transcribing, and after writing the transcription, the researcher got their utterances, classifying with types of illocutionary act and then draw the analysis. The problem is described descriptively according the appropriate theory applied. All the data analysis was done by giving some examples and elaboration on example from the talk show.

\section{Result and Discussion}

\subsection{Commissives}

Commissives are illocutionary acts focuses with speaker's responsibility in taking an activity by the time. Commissives can be divided into planning, offering, and refusing that can be found in this following.

\section{a) Planning}

For example, Oprah Winfrey: And I knew that would not be my life. I knew that I will not be hanging clothes on the line in a backyard in Mississippi, so I was either 4 or 5 years old, and that belief that would not be my life, is what I held on to for the longest of times. I just no matter what believed that there was something bigger, greater, more for me. Those examples are speaker communicate to explained that the speaker allow themselves to make an action in the future. What she was said in the dialogue above consist of a statement about future action, promises that she will not do the same thing in the future. Oprah believed in the future she will not hanging clothes on the line in a backyard Mississippi and she believed that something bigger, greater and more is waiting for her in the future life.

\section{b) Offering}

For example, Ralph Lauren: and I've never forgotten that because even when he said that the world isn't ready for you I thought that was a compliment . Oprah Winfrey: yes. Ralph Lauren: so, what happens girl came along and said "Ralph, would you like to come with me?" and I said I would I'd like to start my own division called it polo. The example from the data above is illocutionary act in offering. The utterance "Ralph, would you like to come with me?" has a meaning that the girl offered help to Ralph Laurent for some action, but Ralph Laurent said that he would start his own division and called it polo.

\section{c) Refusing}

For example, Oprah Winfrey: what was the job? Ralph Lauren: ...when I went to my boss and I said look I'd like to design these times, because I think they could be new. He said, "The world isn't ready for Ralph Lauren."

\section{d) Directives}

Directive is illocutionary acts which is used by the speaker to get something done. Directive can be divided into question, request, and command as follow. 


\section{e) Question}

For example, Oprah Winfrey: so didn't you write yourself a check? I heard that you did. Is that true? ; Jim Carrey: I wrote myself a check for ten million dollars for acting services rendered, and I gave myself five years ther. From the example above it can be seen that the interviewer tried to ask a question in order to get the information they wanted. Oprah requested the answer from the guest to get information. And in this example the guest answered all of the question of Oprah Winfrey. In the first example, Oprah asked Jim Carrey in context of asking for certainty about the information she got.

\section{f) Request}

For example, Sara Blakely: Oprah really talked and hit on how if you just don't give up and believe in yourself, you can accomplish anything and I had this epiphany suddenly like I've literally jumped off the couch, I ran to my room and I grabbed this little thing that I had created for myself to smooth my stomach to keep my low-rise pants in place and never had crossed my mind before this could be something that other women might want or could benefit from. In the first example, it refers to requesting function because Sara Blakely requested to us as the hearer "just don't give up and always believe yourself and you can accomplish anything." Sara requested the hearer to do something about themselves.

Command

For example, Ralph Lauren: look at the weather. Oprah Winfrey: I love the weather, I love everything about this. I can't even explain to you what this means that I'm here.The examples above are categorized as command function. In first example, the reason of Ralph Lauren showed this assist to order Oprah Winfrey to find at the weather at that place.

\subsection{Expressives}

Expressives are kinds of speech acts consists what the speaker feels. Speakers of a language often express feelings to the listener when they speak.

\section{a) Greeting}

For example, Ralph Lauren: hey, how are you? ; Oprah Winfrey: Wow whee, I can't believe I made it. How are you? ; Ralph Lauren: How you doing? Good to see you; Oprah Winfrey: Good to see you, I can't imagine how long I have dreamed of coming here

\section{b) Thanking}

For example, Oprah Winfrey: Thank you so much for tuning in and for logging on at oprah.com for a class... In this case thanking express our grateful to someone for something that they have done in which Oprah wanted to express that grateful to the hearer by saying thank you, because the hearer wanted to turn in and log on at Oprah.com

\section{c) Complimenting}

For example, Sara Blakely: yeah, yeah right, but the journey has been astounding, and I feel like you've been available nearly the entire journey, so I'm pleased to meet you ; Oprah 
Winfrey: I'm proud to meet you ; Oprah Winfrey: ... In all of the years of the Oprah show, Jim Carrey would be one of our greatest teachers. In the first example it showed explained the speaker appreciated the what the other speaker had done and appreciated what other speaker have done. The expression "I'm proud to meet you" actually implied that Sarah Blakely praised to the Oprah Winfrey and on the other way.

\section{d) Expressing Opinion}

For example, JK Rowling: I think the single huge thing that money gave me, and obviously I came from a place, where I was a single mother and it really was hand to mouth at one point... JK Rowling: ... in fact, I'd say I was someone with not much self-belief at all and yet in this one thing in my life I believed. That was the one thing in my life. I felt, "I can tell a story."

In the examples, they used personal point of view about themselves. In the first example told us about JK Rowling has opinion for herself that the biggest thing that money given to her and duly from a place where she was. The second example JK Rowling said that "believed that the one thing in my life I felt I can tell a story." was her opinion because at the beginning she said she was someone with not much self-belief but at the end she has believed that she can tell a story in her life.

\section{e) Expressing Surprise}

For example, Oprah Winfrey: Oh my god over than five millions, five thousands; Sara Blakely: Yeah, I buy an apartment, I know ; Oprah Winfrey: That was amazing; Sara Blakely: It's amazing, I mean these all the men that I was cold calling said this isn't a good idea I don't get it and it just has taken off I believed in it, you were such a big part. From those conversations it can be stated that sentences belong to surprise function, because it was used to express the speaker's expression about being surprised.

\section{f) Expressing Happiness}

For example, Sara Blakely: ... it's just beyond anything I could imagine I very excited to have that pretty to experience firsthand how believing in yourself can change your whole world. The communication above are the examples of the speaker's talk of saying their joy of the facts that happened in the real situation.

\section{g) Expressing Disbelief}

For example, Oprah Winfrey: well know because that is the truth. I mean four years, I did not do that, four years I would cut off... The expressions above show that the speakers are unsure and did not believe about something. In the first example Oprah used utterance "I mean four years, I did not do that" to express her feeling because she didn't believe that what she did for during four years can be a good idea for Sara Blakely to create her own brand.

\subsection{Assertives}

Assertives are those kind of illocutionary act that commit the speaker of the truth to the expressed propositional content. Assertives can be divided into informing, describing, accepting, guessing, predict, and assert. 


\section{a) Informing}

For example, Narrator: JK Rowling legend start with a wonderful kids' book about a vagrant kid wizard, named with a lightning-molded scar. A kid with an enchanted predetermination. A fate shared by his maker. JK Rowling is simply the main made extremely rich person creator ever. Selling in excess of more than four hundred million books spellbinding perusers in 69 dialects and 200 nations around the world. Harry's last part the Deathly Hallows is the quickest selling book ever.

The communication are to inform because they contain information based on JK. Rowling. They told story about Harry potter book created by JK Rowling, which has sold more than four hundred million books in various countries.

\section{b) Describing}

For example, Oprah Winfrey: But since I detected that and was associated with that, and I recall was an extremely still second, it was peaceful and I was still and I was watching her. I could see her right now with the clothespins in her mouth and putting them on the line and seeing the breath, because it was cold, the moisture coming from her lips. The example above describe situation and place. Oprah tried to tell the hearer about what she was seeing at the moment and how it was at that moment by describing it until the hearer could imagine her current situation.

\section{c) Accepting}

For example, Oprah Winfrey: so, this is the first time we've met ; JK Rowling: yes it is; Oprah Winfrey: in the United States, you're known as the first billionaire author; JK Rowling: yeah. The expression which is used by JK Rowling by said that she mean to accepting what was offered in prior situation. Oprah requested clarification about the information which stated that its first time they met in United States and JK Rowling response revealed that she corrected that information.

\section{d) Guessing}

For example, Sara Blakely: I go to craft stores, and look the little bands and things that I thought could maybe go to the end of it... In the first example Sara said "things that I thought could maybe go on" it mean she could find something from a craft store and make something from that stuff. And second example, Sara Blakely told about prediction what event might happen in her life while she still work in her previous job.

\section{e) Predict}

For example, Oprah Winfrey: ...I think that's true for not just people who become known or become famous, I think it's true for everybody who decides for themselves that there is something more, and I want to listen to what that is and be guided by that. In this example Oprah said that "I think that's true for not just people who become known or become famous I think it's true for everybody who decides for themselves that there is something more". She said that because many people didn't believe themselves and many people life by listening to other people opinions, so Oprah predicted that people who become famous because they decided for 
themselves. That's what the Oprah did, she chose to decide her life until now, and this day Oprah could be known by many people.

\section{f) Assert}

For example, Oprah Winfrey: but, this is not interesting? cause in the first book, when Harry is being dropped off at his uncle's, it is predicted?; JK Rowling: one day every child in the world will know his name; Oprah Winfrey: one day every child in the world will know his name. The sentence in bold type to the above example "One shot one day every child in the world will know his name" is an utterance by JK Rowling. She believed that the story she wrote someday will be read by everyone. Even though in the beginning she always fails when trying to publish her book, JK Rowling always believes that every children in the world will know Harry Potter.

\section{Conclusion}

After all data have been analyzed, it is found four kinds of illocutionary acts in the Oprah's Lifeclass talk show they are commissives, directives, expressives, and assertives. Besides that, there are 19 type of illocutionary acts expression found in Oprah's Lifeclass Talk Show, they are planning, offering, refusing, question, request, command, greeting, thanking, complimenting, expressing opinion, expressing surprise, expressing happiness, expressing disbelief, informing, describing, accepting, guessing, predict, and assert.

\section{References}

[1] L. . Horn and G. Ward, The Handbook of Pragmatics. UK: Blackwell Publisher, 2006.

[2] G. Yule, Pragmatics: Oxford Introductions to Language Study. USA: Oxford University Press, 1996.

[3] K. Bach and R. M. Harnish, Linguistic Communication and Speech Acts. Cambridge: MIT Press, 1979.

[4] J. L. Austin, How to Do Things with Word. London: Oxford University Press, 1962.

[5] L. T. Budiasih, Andayani, and M. Rohmadi, "Illocution on Speech Acts of Foreign Students in Indonesian Learning," Parole: Journal of Linguistics and Education, vol. 6, no. $2,2016$.

[6] Herman, "Illocutionary Acts Analysis of Chinese in Pematangsiantar," International Journal of Humanities and Social Science Invention, vol. 4, no. 12, 2015. 